Saint Louis University School of Law

Scholarship Commons

All Faculty Scholarship

2019

Worker Participation, Sustainability, and the Puzzle of the Volkswagen Emissions Scandal

Matthew T. Bodie

Follow this and additional works at: https://scholarship.law.slu.edu/faculty

Part of the Business Organizations Law Commons, and the Labor and Employment Law Commons 


\title{
Worker Participation, Sustainability, and the Puzzle of the Volkswagen Emissions Scandal
}

In Beate Sjåfjell and Christopher M. Bruner (eds.), Cambridge Handbook of Corporate Law, Corporate Governance and Sustainability (Cambridge University Press, Forthcoming).

University of Oslo Faculty of Law Research Paper No. 2019-23

Saint Louis University School of Law Legal Studies Research Paper Series No. 2019-20

Matthew T. Bodie

Saint Louis University School of Law

Date Written: May 6, 2019

\begin{abstract}
In September 2015, Volkswagen's "clean diesel" technology was exposed as a sham. Not only were the company's vehicles discharging dangerously high levels of nitrogen oxide, but VW had intentionally rigged its emissions systems to cheat on environmental tests. In the wake of resignations and criminal investigations, the company's governance system came under justifiable attack. Were VW's famously worker-friendly governance policies to blame? This Chapter examines the root causes of the emissions scandal and concludes that VW's governance culture suffered from dictatorial leadership as well as a cozy relationship between management and labor leaders. This culture of complacency led to a lack of accountability at key levels, including executives, shareholders, and regulators. In addition, despite its worker-oriented governance structure, Volkswagen's internal management is still organized along traditional hierarchical lines. Empowered workers, participating at all levels of company governance, would provide a stronger internal culture of compliance, innovation, and sustainability.
\end{abstract}

Keywords: codetermination, governance culture, accountability, VW, supervisory board, compliance

\section{Suggested Citation:}

Bodie, Matthew T., Worker Participation, Sustainability, and the Puzzle of the Volkswagen Emissions Scandal (May 6, 2019). In Beate Sjåfjell and Christopher M. Bruner (eds), Cambridge Handbook of Corporate Law, Corporate Governance and Sustainability (Cambridge University Press, Forthcoming. 